\title{
Dynamic Relationship between Gross Domestic Product and Domestic Investment in Rwanda
}

\author{
Bruno Ocaya ${ }^{1, *}$, Charles Ruranga ${ }^{1,2}$, \& William Kaberuka ${ }^{1}$ \\ ${ }^{1}$ School of Statistics and Planning, Makerere University, Kampala, Uganda \\ ${ }^{2}$ Department of Applied statistics, National University of Rwanda, Butare, Rwanda \\ *Corresponding author: School of Statistics and Planning, Makerere University, P.O.Box 7062, Kampala, Uganda \\ E-mail: bocaya@isae.mak.ac.ug
}

Received: October 28, 2012

Accepted: November 19, 2012

Online Published: December 13, 2012

doi:10.5430/wje.v2n6p79

URL: http://dx.doi.org/10.5430/wje.v2n6p79

\begin{abstract}
This study uses a VAR model to analyse the dynamic relationship between gross domestic product (GDP) and domestic investment (DI) in Rwanda for the period 1970 to 2011. Several selection lag criteria chose a maximum lag of one, and a bivariate VAR(1) model specification in levels was adopted. Unit root tests show that both GDP and DI series are nonstationary in levels but stationary in first differences, implying that both are integrated of order one I(1). Tests of cointegration established that GDP and DI are $\mathrm{CI}(1,1)$, suggesting there is a long-run equilibrium relationship between the two series. The error correction model indicates that DI adjusts to GDP with a lag whereby 0.2 percent of the discrepancy between long-term and short-term DI is corrected within the year. Granger causality tests show that there is unidirectional causality where GDP causes DI. The bivariate VAR (1) was unstable when estimated at levels, but was stable in first differences. Finally it was found out that GDP almost perfectly predicts DI in the estimated VAR (1) model. The forecasted value of DI in 2011 was $22.6 \%$ of GDP while the actual value was $22.7 \%$ of GDP. The small discrepancy may be attributed to the appropriate policy measures the Rwandan government and the private sector federation have thus far taken to facilitate investors in their businesses.
\end{abstract}

Keywords: Gross Domestic Product (GDP); Domestic Investment (DI); Granger Causality; Cointegration; Vector Autoregression (VAR) and Vector Error Correction Model (VECM)

\section{Introduction}

Investment is a powerful channel for innovation, economic growth and therefore poverty reduction. Recent empirical studies have established linkages between investment and economic growth (e.g., Barro, 1991; Barro \& Lee, 1993; Ben-David, 1998; Collier \& Gunning, 1999; Ghura \& Hadjimichael, 1996; Hernandez, 2000; Khan \& Reinhart, 1990; Ndikumana, 2000). Analysis of causality between economic growth and domestic investment conducted in different countries are marred with ambiguities and inconclusive results. For example, several researchers have found bi-directional relationship (Tang, Selvanathan \& Foreign, 2008; Tan \& Lean, 2010). Others found the direction of causality to be from economic growth to domestic investment (Choe, 2003; Quin, Cagas, Quising \& He, 2006) while some found the direction of causality to be from domestic investment to economic growth (Villa, 2008). Also in other studies, private investment was shown to be super-exogenous, meaning investment was the primary determinant of economic growth (Montek, 2002).

Rwanda has made significant progress in poverty reduction and has improved the conditions of doing business (World Bank, 2011). Different policies have been adopted in order to increase gross domestic product and promote domestic investment but there has been no empirical study which has attempted to establish the relationship between the growth of GDP and investment. In other words, the question about the forecasting power of investment growth and economic growth remains a moot point. The few and sketchy studies that exist are mainly descriptive in nature and offer limited understanding of the relationship for policy prescription in Rwanda.

Rwanda is a land-locked country located in east and central Africa. It borders Uganda to the north, Tanzania to the east, the Democratic Republic of Congo to the west, and Burundi to the south. Rwanda covers 26,338 square 
kilometres of land. The current population is about 10.7 million, exhibiting a very high population density of 407 inhabitants per square kilometre. Agriculture and Services are the principal sectors contributing to more than $80 \%$ of GDP. Coffee and tea are the main primary products exported and they constitute $40 \%$ of export earnings. Due to limited diversification of its economy, Rwanda's balance of payments has continued to be unfavourable with current account balance always in the negative.

After the 1994 genocide, Rwanda Government embarked on a new development path. The new government ushered in peace, political stability, good governance and minimal corruption among others. As a result, Rwanda's economy has since 2002 been experiencing robust, resilient and sustained GDP growth in the East African region averaging over eight percent annually. The Rwanda government has also made significant efforts to promote private sector led growth to spur domestic investment currently at 22\% of GDP (World Bank, 2012). Extreme poverty has fallen from $40 \%$ in 2000 to $24 \%$ in 2011 . Though still high, the percentage of the population living below poverty line has significantly reduced from $77.8 \%$ to $44.9 \%$ between 1994 and 2011 respectively (NISR, 2011).

The objective of this paper is to analyse and establish the unknown feedback mechanism between GDP and DI for shaping the development policy in Rwanda. A bivariate VAR model was used to analyse the dynamic relationship between gross domestic product and domestic investment in Rwanda for the period 1970 to 2011.

\section{Data and Methodology}

\subsection{Data}

The data used for our analysis consists of 42 observations, collected from World Bank publications for the period 1970-2011 (World Bank, 2012). The variables analysed are GDP (at 2000 US\$ prices) and gross fixed capital formation as percent of GDP, proxies of economic growth and domestic investment respectively. Economic growth represents the increase in the amount of the goods and services produced by an economy over time. It is conventionally measured as percentage rate of increase in real gross domestic product. Domestic investment represents gross fixed capital formation or gross domestic fixed investment. It includes land improvements, plant, machinery, equipment purchases, commercial and industrial buildings; and construction of roads, railways, schools, offices, hospitals and private residential dwellings.

In order to have a feel of the data used, we first plotted the time series for GDP and DI as shown in Figure 1 and Figure 2

GDP (constant 2000 US\$ in million) Domestic investment(current US\$ in million)

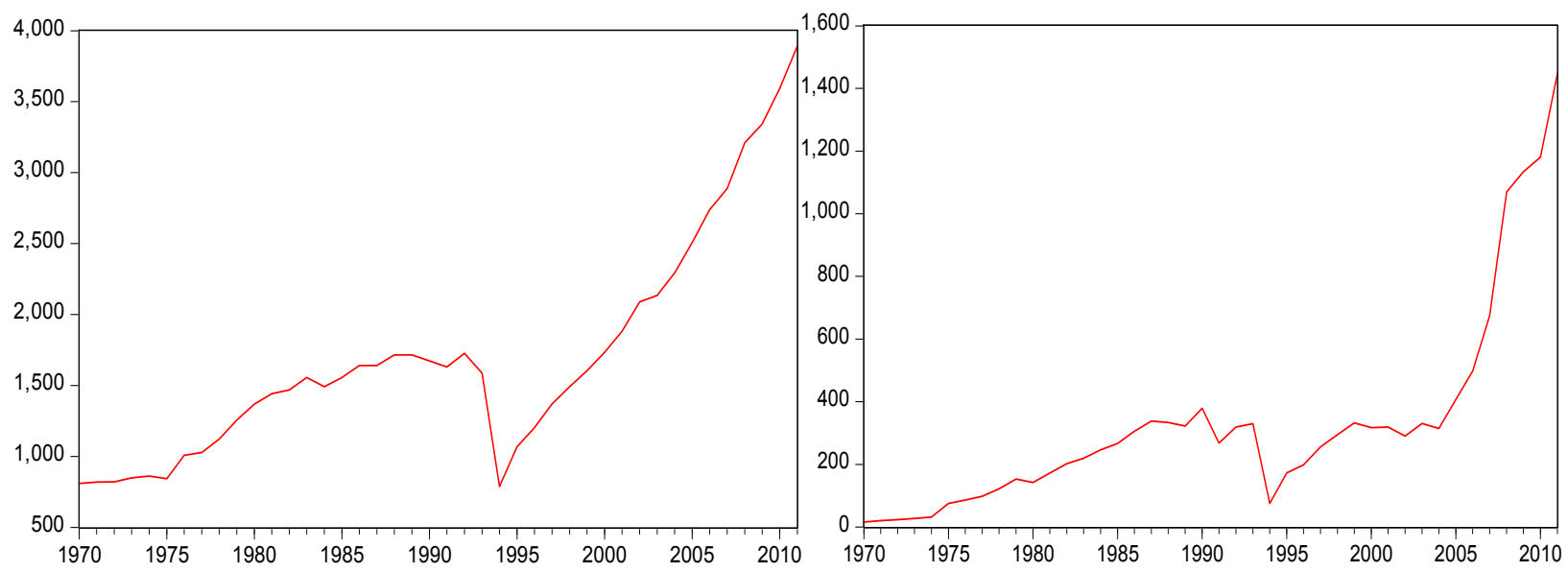

Figure 1: GDP and DI, Rwanda, 1970-2011 (annually)

Source: World Bank, World development indicators, 2012. 
Domestic investment (\% of GDP)

GDP annual growth

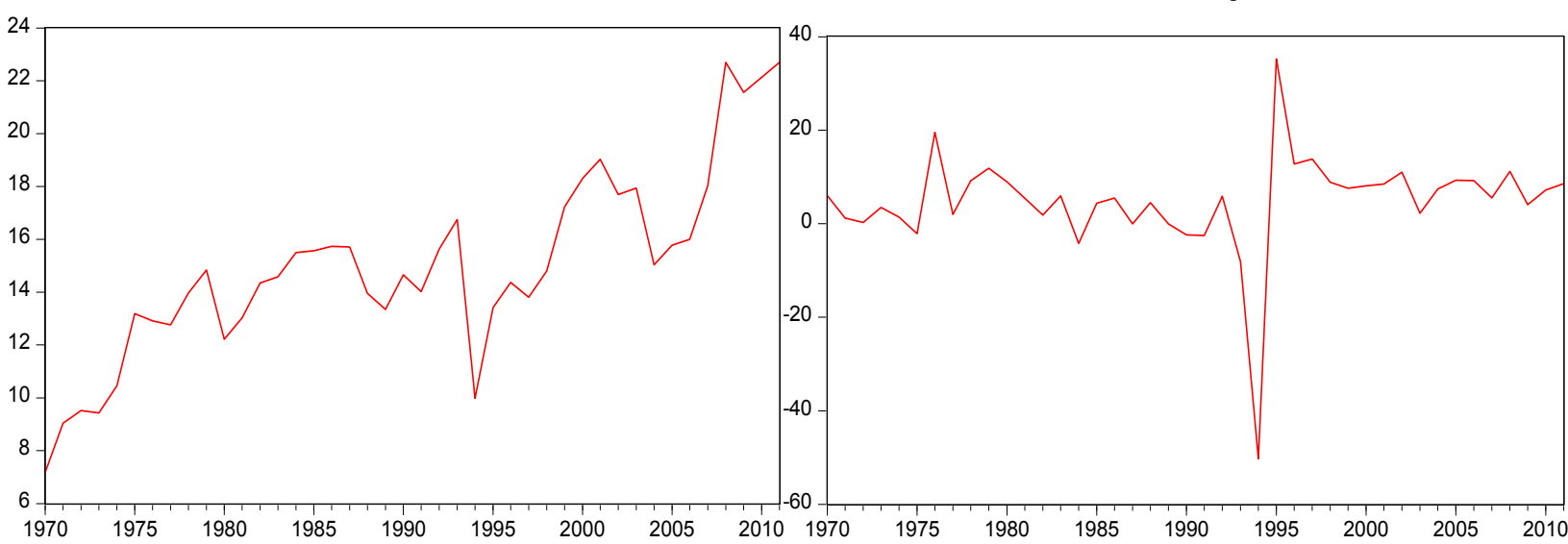

Figure 2: DI as a share of GDP and GDP growth, Rwanda, 1970-2011 (annually)

Source: World Bank, World development indicators, 2012.

Except for the brief period of conflict and genocide in Rwanda in 1994, Figure 1 shows there has been an upward trend in the time series for both GDP and DI. Between 1970 and 2011, Rwanda's DI increased more than seventy times, from US\$15.8 million to US\$1.4 billion. Figure 2 shows that the annual growth rate of GDP plummeted to $-50 \%$ (genicide period) and theafter fluctuating around $8 \%$. However, DI as a share of GDP exhibited an upward trend increasing from $7 \%$ in 1970 to $22.7 \%$ in 2011. Both graphical representations in Figure 1 and Figure 2 indicate general trending and fluctuation of GDP and DI series, implying their nonstationarity.

\subsection{Model Specification}

The general form of bivariate vector autoregressive (VAR model used to analyse the dynamic relationship between GDP and DI is expressed as

$$
\begin{gathered}
G D P_{t}=\delta+\sum_{i=1}^{p} \alpha_{1 i} G D P_{t-i}+\sum_{j=1}^{p} \beta_{1 j} D I_{t-j}+u_{1 t} \\
D I_{t}=\theta+\sum_{i=1}^{p} \alpha_{2 i} G D P_{t-i}+\sum_{j=1}^{p} \beta_{2 j} D I_{t-j}+u_{2 t}
\end{gathered}
$$

where $\delta$ and $\theta$ are intercepts, $\alpha_{1 i}, \alpha_{2 i}, \beta_{1 i}, \beta_{2 i}$ represent coefficients, GDP is gross domestic product (constant 2000 in US\$), DI is domestic investment as percent of GDP, $t(t=1,2, \ldots, 42)$ is time period and $p$ represents equal lags for GDP and DI. The $u_{1 t}, u_{2 t}$ are the stochastic error terms, also known as shocks, innovations or impulses with the assumptions:

(i) $E\left(u_{1 t}\right)=E\left(u_{2 t}\right)=0$

(ii) $E\left(u_{1 t} u_{2 t}\right)=\sum=\left(\begin{array}{cc}\operatorname{var}\left(u_{1 t}\right) & \operatorname{cov}\left(u_{1 t} u_{2 t}\right) \\ \operatorname{cov}\left(u_{1 t} u_{2 t}\right) & \operatorname{var}\left(u_{2 t}\right)\end{array}\right)$

with

$$
\begin{aligned}
& E\left(u_{i t} u_{i t}\right)=\sigma_{i}^{2} \text { for } i=1,2 \\
& E\left(u_{i t} u_{i \tau}\right)=0 \text { for } t \neq \tau .
\end{aligned}
$$

\section{Results and Discussions}

The following sections present empirical time series analysis on the relationship between GDP and DI(Note 1): 


\subsection{Lag Order Selection}

Determination of maximum lag $p$ was carried out using Akaike information criteria (AIC) and Schwarz information criteria. The lower the values of Akaike and Schwarz statistics, the better is the model. Incidentally, all the lag criteria reported by EViews chose lag one, suggesting a bivariate VAR (1) model as the appropriate for analysing the dynamic relationship between GDP and DI. These results are shown in Table 1.

Table 1: VAR Lag Order selection

VAR Lag Order Selection Criteria

Endogenous variables: GDP DI

Exogenous variables: $\mathrm{C}$

Sample: 19702011

Included observations: 39

\begin{tabular}{|c|c|c|c|c|c|c|}
\hline Lag & $\log \mathrm{L}$ & $\mathrm{LR}^{\mathrm{a}}$ & $\mathrm{FPE}^{\mathrm{b}}$ & $\mathrm{AIC}^{\mathrm{c}}$ & $\mathrm{SC}^{\mathrm{d}}$ & $\mathrm{HQ}^{\mathrm{e}}$ \\
\hline 0 & -385.7850 & NA & 1484637. & 19.88641 & 19.97172 & 19.91702 \\
\hline 1 & -318.9473 & $123.3928^{*}$ & $59208.31 *$ & $16.66396^{*}$ & $16.91989^{*}$ & $16.75579 *$ \\
\hline 2 & -317.6407 & 2.278132 & 68129.82 & 16.80209 & 17.22864 & 16.95513 \\
\hline 3 & -317.4289 & 0.347633 & 83154.82 & 16.99635 & 17.59353 & 17.21061 \\
\hline
\end{tabular}

Note. * indicates lag order selected by the criterion

${ }^{a}$ LR: sequential modified LR test statistic (each test at 5\% level)

${ }^{\mathrm{b}}$ FPE: Final prediction error

${ }^{c}$ AIC: Akaike information criterion

${ }^{\mathrm{d}}$ SC: Schwarz information criterion

${ }^{\mathrm{e}}$ HQ: Hannan-Quinn information criterion

The VAR model after lag determination becomes

$$
\begin{gathered}
G D P_{t}=\alpha_{10}+\alpha_{11} G D P_{t-1}+\alpha_{12} D I_{t-1}+u_{1 t} \\
D I_{t}=\alpha_{20}+\alpha_{21} G D P_{t-1}+\alpha_{22} D I_{t-1}+u_{2 t}
\end{gathered}
$$

or

$$
\left[\begin{array}{l}
G D P_{t} \\
D I_{t}
\end{array}\right]=\left[\begin{array}{l}
\alpha_{10} \\
\alpha_{20}
\end{array}\right]+\left(\begin{array}{ll}
\alpha_{11} & \alpha_{12} \\
\alpha_{21} & \alpha_{22}
\end{array}\right)\left[\begin{array}{l}
G D P_{t-1} \\
D I_{t-1}
\end{array}\right]+\left[\begin{array}{l}
u_{1 t} \\
u_{2 t}
\end{array}\right]
$$

\subsection{Unit Root Tests}

Tests for unit roots were undertaken in order to determine the stationarity of the series for GDP and DI. The Augmented Dickey-Fuller (ADF) tests provided in Table 2 show that GDP and DI are not stationary at levels. Instead, their first differences were found to be stationary, in Table 3, implying that both GDP and DI are integrated of order one $[\mathrm{I}(1)]$. 
Table 2: The results of unit root test in levels

\begin{tabular}{|c|c|c|c|c|c|c|}
\hline \multirow{3}{*}{$\begin{array}{l}\text { Included } \\
\text { in test } \\
\text { equation }\end{array}$} & \multicolumn{3}{|c|}{ GDP $^{a}$} & \multicolumn{3}{|c|}{ DI $^{\mathbf{b}}$} \\
\hline & \multirow[t]{2}{*}{$\begin{array}{l}\text { ADF Test } \\
\text { Statistic }\end{array}$} & \multicolumn{2}{|c|}{$\begin{array}{l}\text { Critical Value at different levels } \\
\text { of significance }\end{array}$} & \multirow[t]{2}{*}{$\begin{array}{ll}\text { ADF } & \text { Test } \\
\text { Statistic } & \end{array}$} & \multicolumn{2}{|c|}{$\begin{array}{l}\text { Critical Value at different } \\
\text { levels of significance }\end{array}$} \\
\hline & & $1 \%$ & $5 \%$ & & $1 \%$ & $5 \%$ \\
\hline $\begin{array}{l}\text { Constant \& } \\
\text { trend }\end{array}$ & 0.254149 & -4.198503 & -3.523623 & -3.188530 & -4.198503 & -3.523623 \\
\hline Constant & 1.929356 & -3.600987 & -2.935001 & -1.777599 & -3.600987 & -2.935001 \\
\hline
\end{tabular}

${ }^{\mathrm{a}}$ GDP represents Gross Domestic Product

${ }^{\text {b }}$ DI represents Domestic Investment

The null hypothesis of existence of unit root is not rejected since the Augmented Dickey-Fuller (ADF) test statistics are lower than the absolute critical values at 1\% and 5\% significant levels. These results establish that GDP and DI are non stationary in levels. However Table 3 rejects the null hypothesis of unit roots for both GDP and DI in their first differences because the absolute values of the ADF are less than the stipulated absolute critical values at $1 \%$ and 5\% significant levels. Results obtained using Phillips-Perron tests for unit roots arrive at similar conclusions.

Table 3: The results of unit root tests in first differences

\begin{tabular}{|c|c|c|c|c|c|c|}
\hline \multirow{3}{*}{$\begin{array}{l}\text { Included } \\
\text { in test } \\
\text { equation }\end{array}$} & \multicolumn{3}{|c|}{ \&DP ${ }^{a}$} & \multicolumn{3}{|c|}{ め) } \\
\hline & \multirow[t]{2}{*}{ ADF Test Statistic } & \multicolumn{2}{|c|}{$\begin{array}{l}\text { Critical Value at different } \\
\text { levels of significance }\end{array}$} & \multirow[t]{2}{*}{ ADF Test Statistic } & \multicolumn{2}{|c|}{$\begin{array}{l}\text { Critical Value at different } \\
\text { levels of significance }\end{array}$} \\
\hline & & $1 \%$ & $5 \%$ & & $1 \%$ & $5 \%$ \\
\hline $\begin{array}{l}\text { Constant \& } \\
\text { trend }\end{array}$ & $-5.587328 * * *$ & -4.205004 & -3.526609 & $-7.481835^{* * *}$ & -4.205004 & -3.526609 \\
\hline Constant & $-5.103964 * * *$ & -3.605593 & -2.936942 & $-7.579278 * * *$ & -3.605593 & -2.936942 \\
\hline
\end{tabular}

Cointegration tests were used to determine the existence of long-run equilibrium relationship between GDP and DI. The Augmented Engle-Granger test for cointegration was adopted for this purpose. This test involves unit root tests on residuals obtained from the estimation of the following models:

$$
\begin{aligned}
& \mathrm{GDP}_{t}=\beta_{0}+\beta_{1} \mathrm{DI}_{t}+e_{1 t} \\
& \mathrm{DI}_{t}=\alpha_{0}+\alpha_{1} \mathrm{GDP}_{t}+e_{2 t}
\end{aligned}
$$

The ADF was applied on $\hat{e}_{1 t}$ and $\hat{e}_{2 t}$ to test for unit roots. The tests were based on testing the significance of $\phi$ and $\theta$ for the following residual models:

$$
\begin{gathered}
\Delta \hat{e}_{1 t}=\phi e_{1 t-1}+\varepsilon_{1 t} \\
\Delta \hat{e}_{2 t}=\theta e_{2 t-1}+\varepsilon_{2 t} .
\end{gathered}
$$

The results of the estimation of equations (7) and (8) are presented in Table 4(a) and 4(b) respectively: 
Table 4(a)

Augmented Dickey-Fuller Test Equation

Dependent Variable: $\Delta \hat{e}_{1 t}$

Method: Least Squares

Sample (adjusted): 19712011

Included observations: 41 after adjustments

\begin{tabular}{lcllr}
\hline \multicolumn{1}{c}{ Variable } & Coefficient & Std. Error & t-Statistic & Prob. \\
\multicolumn{1}{c}{$\hat{e}_{1 t-1}$} & -0.300829 & 0.115390 & -2.607060 & 0.0128 \\
\hline & 0.145191 & Mean dependent var & 2.205344 \\
R-squared & 0.145191 & S.D. dependent var & 293.3920 \\
Adjusted R-squared & 271.2583 & Akaike info criterion & 14.06811 \\
S.E. of regression & 2943242. & Schwarz criterion & 14.10990 \\
Sum squared resid & -287.3962 & Hannan-Quinn criter. & 14.08333 \\
Log likelihood & 1.847711 & & \\
Durbin-Watson stat & & & \\
& & & \\
\end{tabular}

Table 4(b)

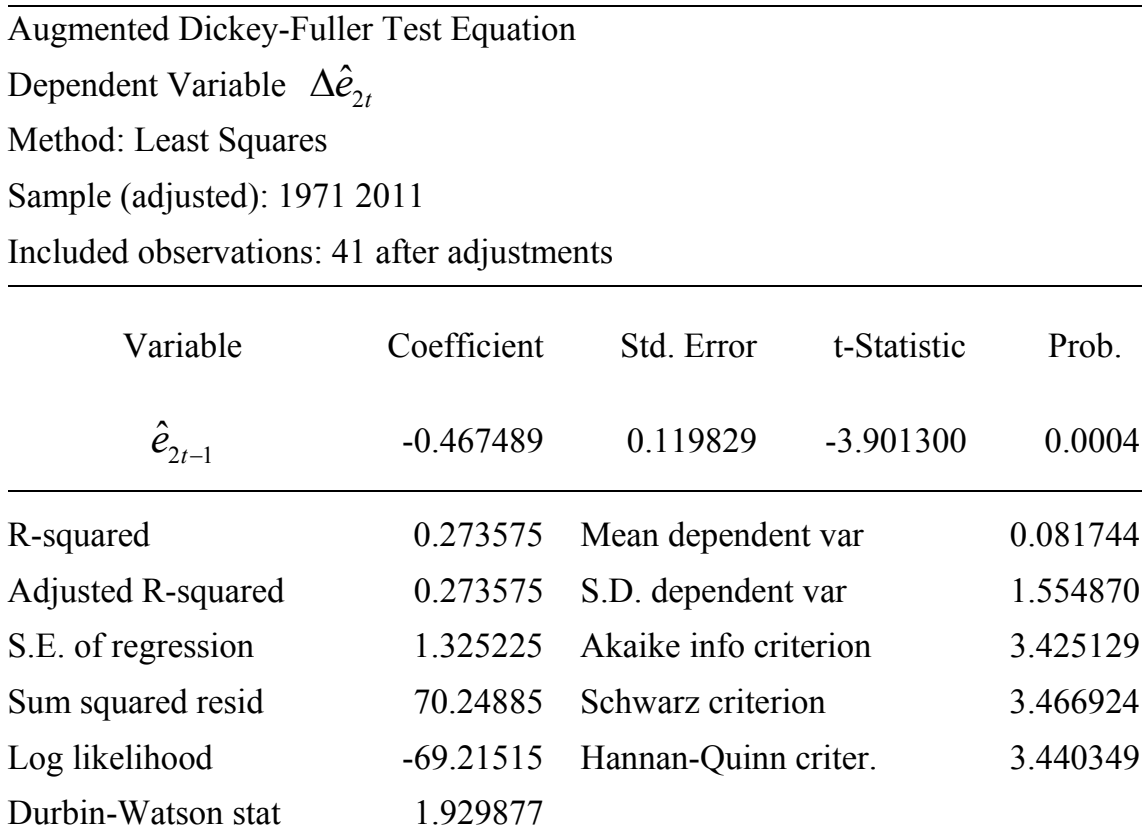

The null hypotheses of no-cointegration or unit root are rejected in both models, implying that GDP and DI are cointegrated of order 1,1 [i.e., GDP, DI $\square \mathrm{CI}(1,1)]$. This verifies that there is a long-run equilibrium relationship between GDP and DI in Rwanda. Similar conclusions were also obtained using the Johansen cointegration test.

\subsection{Vector Error Correction Model (VECM)}

We have found that GDP and DI are each I(1) and co-integrated of order 1,1. With cointegration present, there exists a dynamic interrelationship between the two variables with a disequilibrium correction error term given by the 
following VECM

$$
\begin{aligned}
& \Delta G D P_{t}=\alpha_{10}+\beta E C_{t-1}+\alpha_{11} \Delta G D P_{t-1}+\alpha_{12} \Delta D I_{t-1}+\varepsilon_{1 t} \\
& \Delta D I_{t}=\alpha_{20}+\beta_{2} E C_{t-1}+\alpha_{21} \Delta G D P_{t-1}+\alpha_{22} \Delta D I_{t-1}+\varepsilon_{2 t}
\end{aligned}
$$

where $E C_{t-1}$ represents the error correction component of the model. The estimates of the vector error-correction model are as follows:

$$
\begin{aligned}
& \triangle G D P_{t}=63.46219+0.001022 E C_{t-1}+0.352458 \Delta G D P_{t-1}-29.93540 \Delta D I_{t-1} \\
& t=[2.13337] \quad[0.01842] \quad[1.78619] \quad[-1.57162] \\
& F(3,36)=1.264, \operatorname{Prob}(F \text {-statistic })=0.301 \\
& \Delta D I_{t}=0.296464+0.001528 E C_{t-1}+0.001044 \Delta G D P_{t-1}-0.074123 \Delta D I_{t-1} \\
& t=[1.01524] \quad[2.80681] \quad[0.53921] \quad[-0.39643] \\
& F(3,36)=3.259, \operatorname{Prob}(F \text {-statistic })=0.0324
\end{aligned}
$$

The t-ratios on the coefficients of $E C_{t-1}, \Delta G D P_{t-1}$ and $\Delta D I_{t-1}$ in the $\Delta G D P_{t}$ equation are all individually insignificant. They are also collectively insignificant as indicated by the F-statistic. This implies that GDP does not respond to disequilibrium between itself and DI. The coefficient of $E C_{t-1}$ in the $\triangle D I_{t}$ equation is positive and statistically significant, suggesting that DI adjusts to GDP with a lag. Approximately 0.1528 percent of the discrepancy between long-term and short-term DI is corrected within the year. These results underscore the irrelevance of the GDP equation and the appropriateness of DI equation as was established by Granger causality tests in the next section.

\subsection{Granger Causality}

The Granger-causality tests investigate if a scalar " $y$ " can help forecast another scalar" $x$ ". If it doesn't, then we say that $y$ does not Granger cause " $x "$ (Hamilton, 1994). In other words, " $y$ " does not help in predicting" $x "$. Granger Causality test is generally sensitive to the number of lags adopted for the VAR model. Given that the assumptions in equations (1) and (2) hold, we investigated the following four possible cases of bilateral causality between GDP and DI (Gujarati \& Porter, 2009)

1) Unidirectional causality from DI to GDP which is indicated if the estimated coefficients on the lagged DI in (1) are statistically different from zero as a group (i.e., $\sum \beta_{1 j} \neq 0$ ) and the set of estimated coefficients on the lagged GDP in (2) is not statistically different from zero (i.e., $\sum \alpha_{2 i}=0$ ).

2) Conversely, unidirectional causality from GDP to DI exists if the set of lagged DI coefficients in (1) is not statistically different from zero (i.e., $\sum \beta_{1 j}=0$ ) and the set of lagged GDP coefficients in (2) is statistically different from zero (i.e., $\sum \alpha_{2 i} \neq 0$ ).

3) Feedback, or bilateral causality, suggested when the sets of DI and GDP coefficients are statistically significantly different from zero in both regressions. 
4) Finally, independence suggested when the set of DI and GDP coefficients are not statistically significant in both the regressions.

Using OLS, the following steps were taken to test whether DI "Granger" causes GDP (DI †GDP ;

(i) Regress current GDP on lagged GDP excluding lagged DI. This gives the restricted regression which is used to obtain the restricted residual sum of squares $R_{S S}$.

(ii) Run regression (i) including lagged DI. This gives the unrestricted regression where we obtain the unrestricted residual sum of squares, $R S S_{U R}$.

(iii) The null hypothesis is $H_{0}: \sum \beta_{1 j}=0$, that is, lagged $D I$ terms do not belong in the regression. The null hypothesis in each case is that the variable under consideration does not "Granger cause" the other variable. In this case, DI does not "Granger cause" GDP".

(iv) The general test statistic is given by $F=\frac{\left(R S S_{R}-R S S_{U R}\right) / m}{R S S_{U R} /(n-(2 m+1))} \square F[m,(n-(2 m+1))]$

where $m$ is the number of lagged terms and $n$ is the number of observations used to estimate the model(Note 2). If the p-value is less than 5\%, we reject the null hypothesis that GDP does not Granger-cause DI. By rejecting the null hypothesis, we accept that lagged DI belongs in the regression, another way of saying that DI causes GDP.

(v) Steps (i) to (iv) can be repeated to test the model in equation (2), that is, whether GDP causes DI.

From these steps, the results of the bivariate Granger Causality test are summarized in Table 5

Table 5: Results of Granger causality tests

\begin{tabular}{lclll}
\hline Null Hypothesis & Number of lags & $F$-value & Prob. & Decision \\
\hline DI does not Granger Cause GDP & 1 & 0.54720 & 0.4640 & Do not reject \\
GDP does not Granger Cause DI & 1 & 7.95147 & 0.0076 & Reject at $5 \%$ \\
DI does not Granger Cause GDP & 2 & 1.01294 & 0.3735 & Do not reject \\
GDP does not Granger Cause DI & 2 & 3.38214 & 0.0454 & Reject at $5 \%$ \\
DI does not Granger Cause GDP & 3 & 0.65607 & 0.5851 & Do not reject \\
GDP does not Granger Cause DI & 3 & 2.08297 & 0.1220 & Do not reject \\
\hline
\end{tabular}

These results indicate a unidirectional causality from GDP to DI for the first two lags. Likewise, there is also no causality from DI to GDP for the two lags. However from lag three onwards, it was found out that there was no statistically significant causality from GDP to DI and vice versa. Since our lag selection is one, Rwanda like many other countries have been found to have one way causality from GDP growth to DI growth (Choe, 2003). Hence, policies towards GDP provide useful information for forecasting DI likely to be realized in Rwanda.

\subsection{VAR Estimation}

There is an issue of whether the variables in a VAR need to be stationary for estimation (Hamilton, 1994). Some researchers (Sims, Stock \& Watson, 1990) recommend against differencing even if the variables contain a unit root. They argue that the goal of a VAR analysis is to determine the interrelationships among the variables, not the determination of the parameter estimates. The main argument against differencing is that it "throws away" information concerning the comovements in the data (such as the possibility of cointegrating relationships). Similarly, it is argued that the data need not be detrended. In a VAR, a trending variable will be well approximated by a unit root plus drift. However, the majority view is that the form of the variables in the VAR should mimic the true data generating process (Sims et al., 1990). Taking into account these concerns our bivariate VAR (1) model was estimated in levels using equations (3) and (4) and the results are presented in table 6. 
Table 6: Vector Autoregression Estimates of GDP and DI

Sample (adjusted): 19712011

Included observations: 41 after adjustments

Standard errors in ( ) \& t-statistics in [ ]

\begin{tabular}{|c|c|c|c|c|}
\hline & & $\mathrm{GDP}^{\mathrm{a}}$ & & $\mathrm{DI}^{\mathrm{b}}$ \\
\hline GDP(-1) & 1.117271 & $(0.07207)$ & {$[15.5018]$} & $0.001986(0.00070)[2.81983]$ \\
\hline $\mathrm{DI}(-1)$ & -11.26149 & $(15.2237)$ & {$[-0.73973]$} & $0.492495(0.14876)[3.31073]$ \\
\hline $\mathrm{C}$ & 48.36127 & $(140.480)$ & {$[0.34426]$} & $4.608133(1.37268)[3.35704]$ \\
\hline Adj. R-squared & & 0.953536 & & 0.761513 \\
\hline Sum sq. Resids & & 1075141. & & 102.6545 \\
\hline S.E. equation & & 168.2058 & & 1.643604 \\
\hline F-statistic & & 411.4423 & & 64.86199 \\
\hline Log likelihood & & -266.7515 & & -76.99131 \\
\hline
\end{tabular}

${ }^{\mathbf{a}}$ GDP represents Gross Domestic Product, ${ }^{\mathbf{b}}$ DI represents Domestic Investment

From the t-values the results show that lagged GDP and DI excluding the constant term in the GDP regression is insignificant (i.e., not different from zero). But all coefficients in the DI regression are individually significant at the $5 \%$ level. These results conform with those for the Granger causality tests which suggest the adoption of DI regression for forecasting.

\subsection{VAR Stability}

The regression equations of our estimated VAR (1) in levels are expressed as

$$
\left(\begin{array}{c}
G D P_{t} \\
D I_{t}
\end{array}\right)=\left(\begin{array}{c}
48.36127 \\
4.608133
\end{array}\right)+\left(\begin{array}{cc}
1.117271 & -11.26149 \\
0.001986 & 0.492495
\end{array}\right)\left(\begin{array}{c}
G D P_{t-1} \\
D I_{t-1}
\end{array}\right)
$$

from where we define

$$
A_{*}=\left(\begin{array}{cc}
1.117271 & -11.26149 \\
0.001986 & 0.492495
\end{array}\right) \text {. }
$$

The estimated equations for the same model (output not shown) in first differences were found to be

$$
\left(\begin{array}{c}
\Delta G D P_{t} \\
\Delta D I_{t}
\end{array}\right)=\left(\begin{array}{c}
63.51862 \\
0.380861
\end{array}\right)+\left(\begin{array}{ll}
0.352210 & -30.04025 \\
0.000674 & -0.230943
\end{array}\right)\left(\begin{array}{c}
\Delta G D P_{t-1} \\
\Delta D I_{t-1}
\end{array}\right)
$$

from where we define

$$
A_{* *}=\left(\begin{array}{ll}
0.352210 & -30.04025 \\
0.000674 & -0.230943
\end{array}\right) .
$$

The stability of our VAR (1) model estimated in levels and first differences are then determined using eigenvalue stability condition of matrices $A_{*}$ and $A_{* *}$. By this condition, the eigen values of matrix $A_{*}$ are 1.0792 and 0.53059 , implying that GDP and DI estimated at levels are not stationary since at least one eigenvalue is approximately unity. However fist difference estimation of the model shows that GDP and DI are stationary since all the eigenvalues of matrix $A_{* *}$ which are 0.315 and -0194 lie inside the unit circle. 


\section{Forecasting}

For forecasting, the bivariate VAR (1) was re-estimated in levels for data covering the period 1970-2010. The data for 2011 was excluded for comparison of forecasted and actual values. Table 7 gives the results of the re-estimation of our model.

Table 7: Vector Auto-regression of GDP and DI

Sample (adjusted): 19712010

Included observations: 40 after adjustments

Standard errors in ( ) \& t-statistics in [ ]

\begin{tabular}{|c|c|c|c|c|}
\hline & & GDP & & DI \\
\hline GDP(-1) & 1.106071 & $(0.07596)$ & {$[14.5616]$} & $0.001978(0.00074)[2.65553]$ \\
\hline DI(-1) & -10.83555 & $(15.3952)$ & {$[-0.70382]$} & $0.492795(0.15097)[3.26422]$ \\
\hline $\mathrm{C}$ & 58.11948 & $(143.116)$ & {$[0.40610]$} & $4.615025(1.40342)$ [ 3.28841$]$ \\
\hline R-squared & & 0.945363 & & 0.740036 \\
\hline Adj. R-squared & & 0.942409 & & 0.725984 \\
\hline Sum sq. resids & & 1067482. & & 102.6506 \\
\hline S.E. equation & & 169.8554 & & 1.665635 \\
\hline F-statistic & & 320.0969 & & 52.66379 \\
\hline Log likelihood & & -260.5962 & & -75.60658 \\
\hline
\end{tabular}

${ }^{a}$ GDP represents Gross Domestic Product

${ }^{\text {b }}$ DI represents Domestic Investment

The DI regression equation for forecasting now becomes

$$
\begin{aligned}
& \mathrm{DI}_{2011}=4.615025+0.001978 \mathrm{GDP}_{2010}+0.492795 \mathrm{DI}_{2010} \\
& \mathrm{DI}_{2011}=4.615025+0.001978(3593.742)+0.492795(22.1327)=22.6303 \% .
\end{aligned}
$$

The forecasted value of DI in 2011 is $22.6303 \%$ of GDP while the actual value in 2011 was $22.7 \%$ of GDP. The difference between actual and forecasted is $22.7 \%-22.6303 \%=0.0697 \%$ which represents a small under-prediction. This implies that GDP almost perfectly predicts DI in our bivariate VAR (1) model. The small difference between the actual and forecasted values in DI may be explained by the appropriate policy measures the Rwandan government and the private sector federation have so far taken to facilitate investors in their businesses. The World Bank reports on doing business have shown great improvement in the ranking of Rwanda since 2008 (World Bank, 2012).

\section{Conclusion}

Dynamic relationship between gross domestic product and domestic investment was analysed using time series data of Rwanda for period 1970 to 2011. A bivariate model with lag one selected and considered appropriate for the analysis. The Augmented Dickey-Fuller (ADF) tests and Phillips-Perron tests indicate that GDP and DI are not stationary at levels but their first differences were stationary, meaning that they are integrated of order one.

The Augmented Engle-Granger and Johansen tests of co-integration show that GDP and DI series are co-integrated. While GDP does not appear to respond to disequilibrium between itself and DI, the error correction model establishes that DI adjusts to GDP with a lag. Approximately 0.1528 percent of the discrepancy between long-term and short-term DI is corrected within the year.

Our analysis indicates a unidirectional causality from GDP to DI for the first two lags with no evidence of causality from DI to GDP. The unidirectional causality suggests that policies initiated towards GDP provide important information for predicting DI in Rwanda. The results of the estimation of the bivariate VAR together with 
those of Granger causality tests and error correction model underscore the irrelevance of the GDP equation and the appropriateness of DI equation in our adopted model.

Our estimated bivariate VAR (1) model was found to be stable in first difference, but not in levels. The forecasted value of DI in 2011 is $22.6303 \%$ of GDP while the actual value in 2011 was $22.7 \%$ of GDP. The difference shows that GDP can predict DI with small error of $0.0697 \%$. The small difference between the actual and forecasted values in DI may be explained by the commendable policies the Rwandan government and the private sector federation have been pursuing in promoting investment in the country.

\section{References}

Barro, R. J. (1991). Economic Growth in a Cross Section of Countries. The Quarterly Journal of Economics, 106(2), 407-443. http://dx.doi.org/10.2307/2937943

Barro, R.J., \& Lee, J.W. (1993) Losers and Winners in Economic Growth. Proceedings of the World Bank Annual Conference on Development Economics, ed. M. Bruno and B. Pleskovic, 267-97.

Ben-David, D. (1998). Convergence Clubs and Subsistence Economies. Journal of Development Economics, 55(1), 155-171. http://dx.doi.org/10.1016/S0304-3878(97)00060-6

Choe, J.I. (2003). Do foreign direct investment and gross domestic investment promote economic growth? Review of Development Economics, 7(1), 44-57. http://dx.doi.org/10.1111/1467-9361.00174

Collier, P., \& Gunning, J.W. (1999) Explaining African Economic Performance. Journal of Economic Literature, 37(1), 64-111. http://dx.doi.org/10.1257/jel.37.1.64

Ghura, D., \& Hadjimichael, T. (September 1996). Growth in Sub-Saharan Africa, Staff Papers. International Monetary Fund, 43(3), 605-634. http://dx.doi.org/10.2307/3867556

Gujarati, N. D., \& Porter, D. C. (2009). Basic Econometrics(5 ${ }^{\text {th }}$ edition). New York: McGraw-Hill/Irwin.

Hamilton, J. D. (1994). Time series analysis, Princeton. New Jersey: Princeton university press.

Hernandez-Cata, E. (2000). Raising Growth and Investment in Sub-Saharan Africa: What Can be Done? Policy Discussion Paper: PDP/00/4, International Monetary Fund, Washington, D .C.

Khan, M.S., \& Reinhart, C.M. (1990). Private Investment and Economic Growth in Developing Countries. World Development, 18(1), 19-27. http://dx.doi.org/10.1016/0305-750X(90)90100-C

Montek, S. A. (2002). State-Level Performance under Economic Reforms, Economic Policy Reforms and the Indian Economy, ed. Anne O. Krueger (Chicago and London: University of Chicago Press.

National Institute of Statistics of Rwanda (2011). The third Integrated Household Living Conditions Survey -EICV3, main indicators report. National Institute of Statistics of Rwanda (NISR).

Ndikumana, L. (2000). Financial Determinants of Domestic Investment in Sub-Saharan Africa. World Development 28(2), 381- 400. http://dx.doi.org/10.1016/S0305-750X(99)00129-1

Qin, D., Cagas, M.A., Quising, P., \& He, X.H. (2006). How much does investment drive economic growth in China? Journal of Policy Modeling, 28(7), 751-774. http://dx.doi.org/10.1016/j.jpolmod.2006.02.004

Sims, C. A., Stock, J. H., \& Watson, M. W. (1990). Inference in Linear Time Series Models with some Unit Roots. Econometrica, 58, 113-144. http://dx.doi.org/10.2307/2938337

Tan B. W., \& Lean H. H. (2010). An analysis of dynamic linkages between domestic investment, exports and growth in Malaysia. European Journal of Social Sciences, 16(1), 150-59.

Tang, S., Selvanathan, E. A., \& Selvanathan, S. (2008). Foreign Direct Investment, Domestic Investment, and Economic Growth in China. A Time Series Analysis, Research Paper No. 2008/19. UNU World Institute for Development Economics Research (UNU-WIDER).

Villa, S. (2008). Economic growth, investment and government consumption in Italy: A VAR analysis. ICFAI Journal of Applied Economics, 7(4), 23-32.

World Bank (2011). World Development Indicators Report. The World Bank, Washington, DC.

World Bank (2012). Report on Doing Business. The World Bank, Washington, DC, 20433. 
World Bank (September 2012). World Development Indicators Report. The World Bank, Washington, DC.

\section{Notes}

Note 1. Most of the results were obtained using EViews 7.0 and Stata 12.0 software packages.

Note 2. Note that $(2 m+1)$ is the number of parameters estimated in the unrestricted regression. When the lags for the respective variables are different, $m$ is divided into their components. 